\title{
sciendo
}

CIVIL AND ENVIRONMENTAL ENGINEERING REPORTS

E-ISSN 2450-8594

CEER 2019; 29 (3): 123-133

DOI: $10.2478 /$ ceer-2019-0029

Original Research Article

\section{RARE WEATHER PHENOMENA AND THE WORK OF LARGE-FORMAT ROOF COVERINGS}

\author{
Barbara KSIT ${ }^{1}$, Anna SZYMCZAK-GRACZYK ${ }^{2}$ \\ ${ }^{1}$ Poznan University of Technology, Poznan, Poland \\ ${ }^{2}$ University of Life Sciences in Poznan, Poznan, Poland
}

\begin{abstract}
Wind action belongs to loads that are environmentally variable. Wind action is included in the basic combination of loads, whereas hurricane wind action is classified as a unique combination. Due to large gusts of wind, the roof coverings of large-scale buildings are exposed to detachment of their cover layer. The article presents the effects of overnormative wind, which occurred on January 19, 2018 and was named the cyclone Frederic/David. The purpose of the article is to show that in design of roof coverings made of large-format materials, such as membranes, it is crucial to accept wind load values properly in order to ensure a right spacing between fasteners. The presented results might be an important contribution to the debate on the necessity for increasing the fundamental value of the basic wind velocity in the perimeter and corner zones of large-format roofs.
\end{abstract}

Keywords: wind load, hurricane wind, roof covering, damage, membrane, sail effect

\section{INTRODUCTION}

Rare weather phenomena have always been a matter of concern and led to the loss of people's lives, property damage, devastation of buildings and technical infrastructure.

${ }^{2}$ Corresponding author: Poznan University of Life Sciences, Institute of Construction and Geoengineering, Piątkowska Street 94, 60-649 Poznań, e-mail: anna.szymczakgraczyk@up.poznan.pl, Tel.+48602516345 
The article discusses the action of excessive wind loading on a large-format roof based on a specific example.

There are several types of wind that pose threat to roof structures, particularly large-format ones. Disastrous winds occur in Poland in the period from autumn to spring, they are sometimes very strong and cause significant losses. This might be even catastrophic damage as a result of passing a whirlwind or squall. It is estimated that the velocity in the air vortex is between $50-100 \mathrm{~m} / \mathrm{s}$, and that it is significantly faster than provided in PN-EN 1991-1-4:2008/NA:2010 [14].

Large-format roofs are usually flat roofs with an inclination angle of $1^{\circ}$ to $5^{\circ}$. They are constructed in large cubature buildings and their size often exceeds a dozen or even tens of thousands of square meters. Large-format roofs should characterise with good thermal and hydro insulation properties, high fire resistance, durability and strength regardless of weather conditions [2-4]. The most common design solution for large-format roofs is a four-layer covering. The first part is a construction layer (i.e. https://kb.pl/porady/pokrycia-dachowe-_t/ reinforced concrete slab or trapezoidal sheet), followed by a vapour barrier layer. The third layer is a thermal insulation material covered with an outer sheathing, most often in the form of a heat-welded membrane or a PVC membrane being the last layer of roofing coverage [13]. Among the guideline requirements for roofs, there is an essential recommendation to design thermal insulation in such a way that, apart from meeting the conditions for heat transfer, it would also function as acoustic and fire insulation. The requirements concerning the heat transfer coefficient for roofs are defined in the Regulation of the Minister of Infrastructure as of 12 April 2012 on technical conditions for buildings and their location [9]. The same regulation includes the minimum requirements for the fire resistance class of structural elements, provided for the following criteria: R (fire capacity), E (tightness), and (insulation) [the Polish nomination]. According to the legal provision cited, a roof covering of more than $1000 \mathrm{~m}^{2}$ should be fire-resistant, while thermal insulation should be separated from the inside of the building by a barrier compliant with minimum RE15 fire resistance class. An important requirement for roof layers is the transfer of permanent, variable and exceptional interactions. Permanent loads include self-weight of components, while variable loads are divided into usage- and environmentally-induced actions [8]. They comprise wind, snow or ice action etc. The subject literature contains numerous publications on the impact of loads acting on structures, including analyses of specific design cases or computational simulations [10-12]. The article presents the action of wind load on a large-format roof covering, emphasising the need to consider changes in the standardised values of actions provided in PN-EN 19911-4:2008/NA:2010 [6]. Wind action is a variable, entirely short-lived load, included in the basic combination of loads. Hurricane wind load, on the other hand, consists of a combination of exceptional loads. As regards calculations, the 
basic combination compliant with [6] applies to all structures, whereas this special combination is applied only in cases where due to the purpose, use or location of the building exceptional loads may occur. Wind load on structures and structural elements should be determined taking into account both external and internal pressure exerted by wind. A separate calculation must be made for each type of a structural object. The mean wind velocity at a height " $z$ " above ground level depends on the roughness and relief of the terrain and on the basic wind velocity, which is the 10 minute mean wind velocity with an annual risk of being exceeded of 0.02 , determined at a height of $10 \mathrm{~m}$ above ground level in flat open country terrain. The wind pressure acting on the external surfaces of the structure in a characteristic value according to [6] is described by formula (1.1)

$$
w_{e}=q_{p}\left(z_{e}\right) c_{p e}
$$

where:

$z_{e}$ - reference height for external pressure/ external wind action,

$q_{p}\left(z_{e}\right)$ - peak velocity pressure for calculating the external pressure, which is:

$$
q_{p}\left(z_{e}\right)=c_{e}\left(z_{e}\right) q_{b}
$$

where:

$c_{p e}$ - external pressure coefficient

$c_{e}\left(z_{e}\right)$ - exposure factor, depending on the terrain category

$q_{b}$ - reference mean (basic) velocity pressure:

$$
q_{b}=0.5 \rho v_{b}^{2}
$$

where:

$\rho$ - air density, which is $1,25 \mathrm{~kg} / \mathrm{m}^{3}$

The fundamental value of wind velocity $\left(v_{b}\right)$ should be calculated according to the formula (1.4)

$$
v_{b}=c_{\text {dir }} c_{\text {season }} v_{b .0}
$$

where:

$c_{d i r}$ - directional factor dependent on the direction of wind,

$c_{\text {season }}$ - seasonal factor,

$v_{b .0}$ - fundamental value of the basic wind velocity.

Wind velocities, both average (basic) and instantaneous, not only have a direct effect on load values the structure as a whole has to meet, but also apply to its individual components. In different areas of the world, wind blows with varied strength and velocity, hence considering this weather phenomenon many different zones can be distinguished, where dedicated standards determine specific wind 
loads. In some countries wind zones are identified with numbering (i.e.1, 2, 3), in others by providing a basic value of wind velocity or load value. In Poland the standards include the fundamental values of the basic wind velocity $\left(v_{b .0}\right)$ and the reference mean (basic) velocity pressure $\left(q_{b .0}\right)$, depending on the location within the country, which has been divided into zones and heights above ground level (Fig. 1). Their values are given in Table 1, and they were referenced in the calculations of the analysed case of wind action on the building.

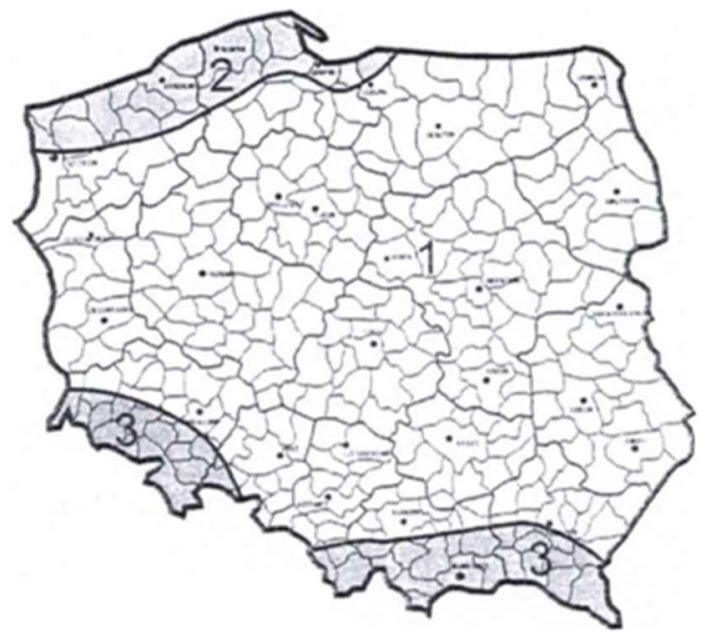

Fig. 1. The division of Poland into wind action zones according to [6]

Table 1 . Fundamental values of the basic wind velocity and wind velocity pressure in individual division zones in Poland according to [6]

\begin{tabular}{|c|c|c|c|c|}
\hline Zones & $\begin{array}{c}v_{b .0} \\
(\mathrm{~m} / \mathrm{s})\end{array}$ & $\begin{array}{c}v_{b .0} \\
(\mathrm{~m} / \mathrm{s})\end{array}$ & $\begin{array}{c}q_{b .0} \\
\left(\mathrm{kN} / \mathrm{m}^{2}\right)\end{array}$ & $\begin{array}{c}q_{b .0} \\
\left(\mathrm{kN} / \mathrm{m}^{2}\right)\end{array}$ \\
\cline { 2 - 5 } & $\begin{array}{c}A \leq \\
300 \mathrm{~m}\end{array}$ & $A>300 \mathrm{~m}$ & $\begin{array}{c}A \leq \\
300 \mathrm{~m}\end{array}$ & $A>300 \mathrm{~m}$ \\
\hline 1 & 22 & $\begin{array}{l}22 \cdot[1 \\
+0.0006(A-300)]\end{array}$ & 0.30 & $0.30 \cdot[1+0.0006(A-300)]^{2}$ \\
\hline 2 & 26 & 26 & 0.42 & 0.42 \\
\hline 3 & 22 & $\begin{array}{l}22 \cdot[1 \\
+0.0006(A-300)]\end{array}$ & 0.30 & $0.30 \cdot[1+0.0006(A-300)]^{2}$ \\
$\cdot\left[\frac{20000-A}{20000+A}\right]$
\end{tabular}

\section{CASE STUDY}

The article presents the action of wind load on hall buildings with a total roof area of $31000 \mathrm{~m}^{2}$. On 19 January 2018, the cyclone Friederike/David reached Poland, moving from the west to the east of the country. In the late evening and night 
hours the wind blew with a velocity of $110 \mathrm{~km} / \mathrm{h}$, and its strongest gusts were in the south of Poland and reached $155 \mathrm{~km} / \mathrm{h}$ [7]. Fig. 2 shows the area affected by the cyclone between 9-10 pm.

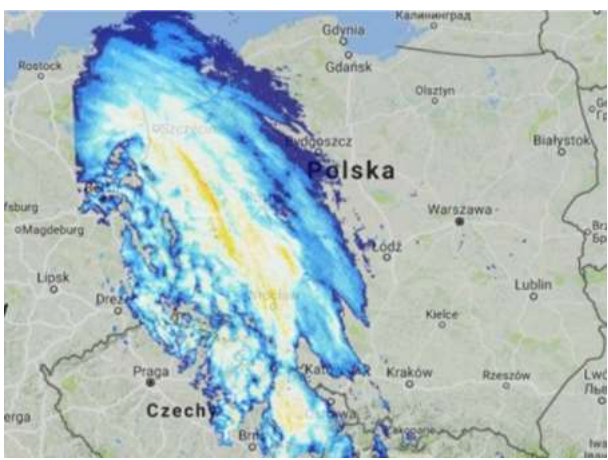

Fig. 2. Velocity and gusts of wind on 19.01.2018, at 9-10 pm (source: www.expressilustrowany.pl)

As a result of the passage of gusty winds over the part of Greater Poland, more than $2500 \mathrm{~m}^{2}$ of the roof covering of the hall no. 1 and approx. $600 \mathrm{~m}^{2}$ of the roof covering of the hall no. 2 were damaged. The buildings have been used as storage facilities of the forwarding company located in the vicinity of Poznan. During the strongly blowing wind there was caused damage to the roof covering - the waterproof roofing membrane was blown off. The mineral wool thermal insulation panels, roof ventilation chimneys and windbreaks of skylight roof casings were also destroyed. The mineral wool of thermal insulation in the areas of damage - a detached roofing membrane - became partly wet and rainwater leaked through a broken roof inside the buildings. Fig. 3-5 show the resulting damage.

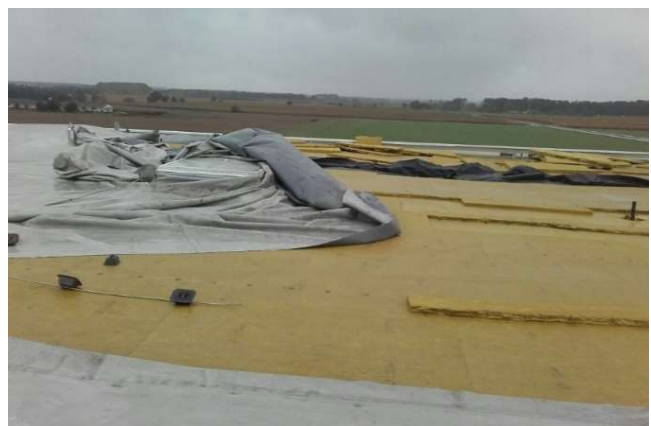

Fig. 3. Damage to the roof of the hall no. 1. A detached membrane in the perimeter zone, exposed thermal insulation 


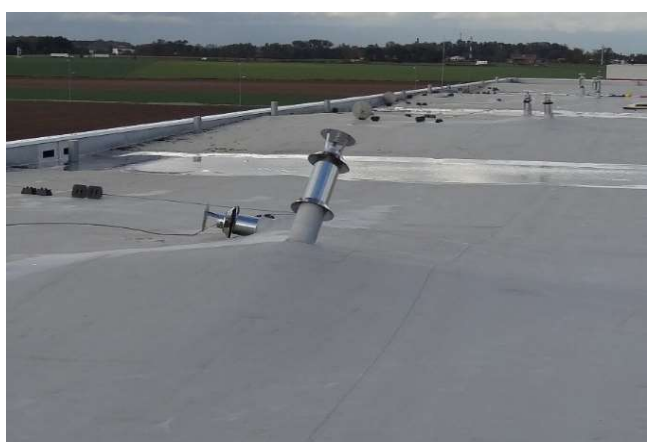

Fig. 4. Damage to the roof of the hall no. 1. Overturned roof ventilation chimneys

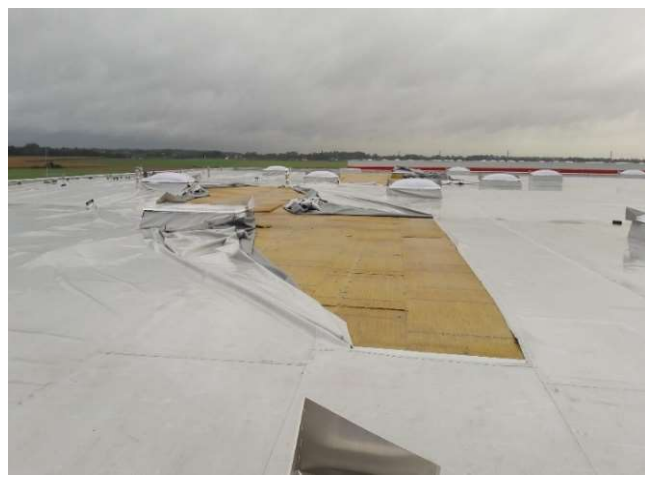

Fig. 5. Damage to the roof of the hall no. 2. A detached membrane in the perimeter zone, exposed thermal insulation<smiles>C1=C[Al]1</smiles>

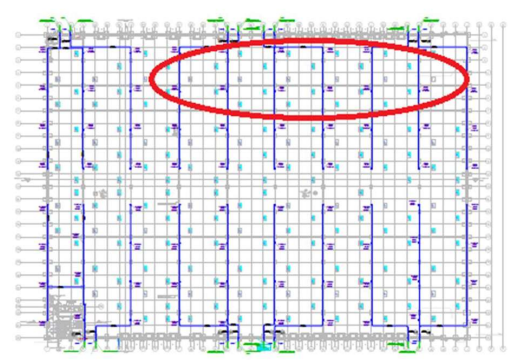

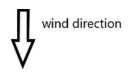

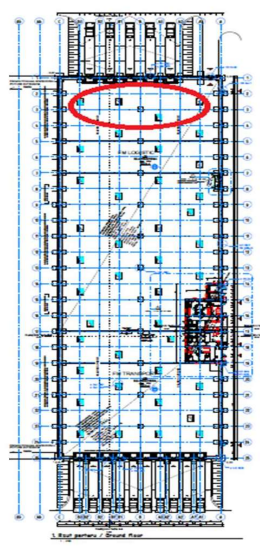

Fig. 6. Projections of the halls with marked locations of damage (hall no. 1 on the left, hall no. 2 on the right) 
In order to identify the causes of damage, it was important to determine its location on the roof surface. Fig. 6 shows the projections of the discussed halls with marked locations of damage to the roof covering.

The roof construction for both of the halls is a full roof with a traditional arrangement of layers. It is made of trapezoidal sheet TR 135/0.75 mm, vaportight insulation made of PE foil $(0.20 \mathrm{~mm})$, mineral wool thermal insulation (130 $\mathrm{mm})$ and watertight PVC foil $(1.2 \mathrm{~mm})$. The height of both halls (1 and 2) at their highest point is $14 \mathrm{~m}$, and the total roof area is approx. $31000 \mathrm{~m}^{2}$. The membrane covering the roof was fastened in the perimeter and corner zones every $50 \mathrm{~cm}$ with the use of plastic fasteners anchored to the structure. In order to analyse the causes of damage, wind load calculations were made based on standard guidelines. The area of Greater Poland belongs to the 1 wind zone according to [6], with the reference mean (basic) velocity pressure $q_{b .0}=0.3 \mathrm{kN} / \mathrm{m}^{2}$ and the value of wind velocity equal to $v_{b .0}=22 \mathrm{~m} / \mathrm{s}$ for roofs up to $300 \mathrm{~m}$ high above sea level. Whereas, the instantaneous velocity value for the above-mentioned data corresponding to zone 1 is $41 \mathrm{~m} / \mathrm{s}$, i.e. $148 \mathrm{~km} / \mathrm{h}$ [14]. At the moment of damage in the area in question there were winds of force in gusts $v_{b .0}=30 \mathrm{~m} / \mathrm{s}$, taking the values of instantaneous velocity between $39-55 \mathrm{~m} / \mathrm{s}$ [7]. Wind power, that is provided in [5] and [6], is lower by $36 \%$ than the one occurring at the time of damage. Wind action is calculated for roof zones, the size of which is closely related to the dimensions of a facility and the direction of wind. For the hall no. 1 - the damage was caused by wind blowing onto the longitudinal wall at an angle of $\theta=0^{\circ}$ and for the hall no. 2 by the wind blowing onto the top wall at an angle of $\theta=90^{\circ}$, respectively. Fig. 7 shows the partition of the roof into zones, taking into account that wind blew at an angle of $\theta=0^{\circ}$ onto the longitudinal wall of the facility, while Fig. 8 shows the diagram of this partition for wind blowing at an angle of $\theta=90^{\circ}$.

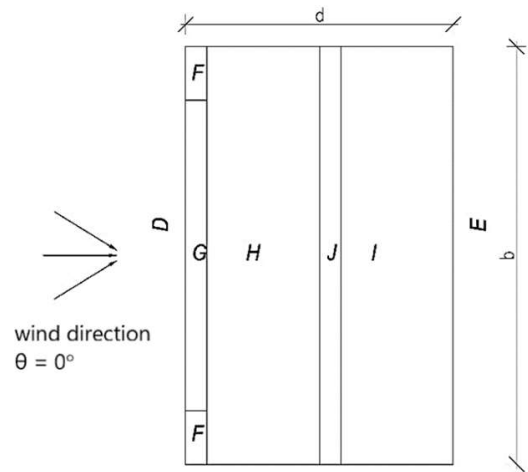

Fig. 7. Partition of the roof into zones for wind blowing at an angle of $\theta=0^{\circ}$ onto the longitudinal wall of the facility 


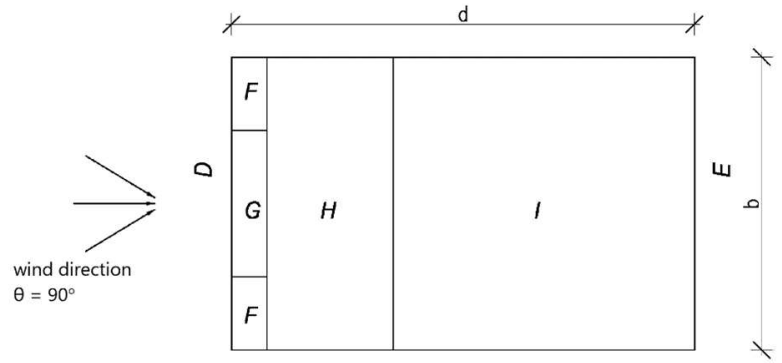

Fig. 8. Partition of the roof into zones for wind blowing at an angle of $\theta=90^{\circ}$ onto the top wall of the facility

The surface of flat roofs is divided into the following zones: corner, perimeter (edge or marginal) and central (inner). The greatest wind load is recorded in the corner zone, slightly smaller in the middle part of the roof.

The computational analysis used data for both of the halls summarised in Table 2. Two basic wind velocities were adopted: the value compliant with the standard load included in [6] of $v_{b .0}=22 \mathrm{~m} / \mathrm{s}$ and the value achieved during the passing of the cyclone Frederic through the Greater Poland region, $v_{\mathrm{b} .0}=30 \mathrm{~m} / \mathrm{s}$.

Table 2. Data accepted for calculation

\begin{tabular}{|c|c|c|c|}
\hline No. & Parameter/symbol/unit & Hall no. 1 & Hall no. 2 \\
\hline 1. & Zone of wind load & 1 & 1 \\
\hline 2. & $h[\mathrm{~m}]$ - height of the wall to the attic & 14 & 14 \\
\hline 3. & $h_{p}[\mathrm{~m}]$ - high of the attic & 0.4 & 0.4 \\
\hline 4. & $b$ or $d[\mathrm{~m}]$ - width & 151.2 & 49.12 \\
\hline 5. & $b$ or $d[\mathrm{~m}]$ - length & 211.0 & 151.2 \\
\hline 6. & $A[\mathrm{~m}]$ - height above sea level & 80.0 & 80.0 \\
\hline 7. & $\begin{array}{l}q_{b .0}\left[\mathrm{kN} / \mathrm{m}^{2}\right]-\text { fundamental value of wind velocity } \\
\text { pressure }\end{array}$ & 0.3 & 0.3 \\
\hline 8. & category of terrain & 1 & 1 \\
\hline 9. & $z[\mathrm{~m}]$ - height above ground level & 14.4 & 14.4 \\
\hline 10. & $\begin{array}{l}v_{b .0}[\mathrm{~m} / \mathrm{s}] \text { - fundamental value of the basic wind } \\
\text { velocity }\end{array}$ & 30 & 22 \\
\hline 11. & $c_{d i r}-$ directional factor of wind & 1 & 1 \\
\hline 12. & $c_{\text {season }}$ - seasonal factor & 1 & 1 \\
\hline 13. & $\rho\left[\mathrm{kg} / \mathrm{m}^{3}\right]$ - air density & 1.25 & 1.25 \\
\hline 14. & $z_{\min }[\mathrm{m}]-$ minimum height & 1 & 1 \\
\hline 15. & $z_{e}[\mathrm{~m}]$ - reference height & 14.4 & 14.4 \\
\hline 16. & $z_{0}[\mathrm{~m}]$ - surface roughness dimension & 0.01 & 0.01 \\
\hline 17. & $k_{l}-$ turbulence coefficient & 1 & 1 \\
\hline 18. & $c_{0}(z)$ - land relief coefficient & 1 & 1 \\
\hline
\end{tabular}




\section{RESULTS AND DISCUSSION}

The calculations of wind action were made according to [6] by using Formulas (1.1-1.4) for the roof partition schedule shown in Fig. 7 and 8 and data from Table 2. The values of wind actions obtained for particular roof zones are given in Table 3 for the fundamental value of the basic wind velocity $v_{b .0}=22 \mathrm{~m} / \mathrm{s}(79.2 \mathrm{~km} / \mathrm{h})$ and $v_{b .0}=30 \mathrm{~m} / \mathrm{s}(108 \mathrm{~km} / \mathrm{h})$.

Table 3. Computational results of wind pressure acting on the external surfaces of the structure

\begin{tabular}{|l|l|c|c|c|c|}
\hline \multirow{2}{*}{ No. } & \multirow{2}{*}{ Roof zone } & \multicolumn{2}{|l|}{$\begin{array}{l}\text { Hall no. 1 } \\
\text { Wind action }\left[\mathrm{kN} / \mathrm{m}^{2}\right]\end{array}$} & \multicolumn{2}{l|}{$\begin{array}{l}\text { Hall no. } 2 \\
\text { Wind action }\left[\mathrm{kN} / \mathrm{m}^{2}\right]\end{array}$} \\
\cline { 3 - 6 } & & $v_{b .0}=22 \mathrm{~m} / \mathrm{s}$ & $v_{b .0}=30 \mathrm{~m} / \mathrm{s}$ & $v_{b .0}=22 \mathrm{~m} / \mathrm{s}$ & $v_{b .0}=30 \mathrm{~m} / \mathrm{s}$ \\
\hline 1. & zone F & -2.26 & -4.19 & -2.26 & -4.19 \\
\hline 2. & zone G & -1.55 & -2.88 & -1.55 & -2.88 \\
\hline 3. & zone H & -0.99 & -1.84 & -0.99 & -1.84 \\
\hline 4. & zone I & -0.28 & -0.52 & -0.28 & -0.52 \\
\hline
\end{tabular}

Wind blowing on buildings causes two types of action: wind pressure and wind suction. The wind pressure is given positive values, whereas the wind suction takes negative values. By analysing the wind suction values provided in Table 3 , a significant increase in wind load in all zones can be observed. The biggest load occurred in the corner zone and at the moment of passing of the cyclone it was by $85 \%$ higher than the standard value of wind load for the basic combination of actions.

\section{CONCLUSIONS}

It was found that the damage was first caused to the corner zone due to increased action of wind pressure, and the further process was of an exponentially increasing nature. The corners of large-surface structures are very often places affected by a total edge load. The sail effect, which accompanied the detached membrane floating in the air, removed the roof cover to a greater extent and led to further adverse consequences in the course of damage. The fasteners were designed to meet the fundamental value of the basic wind velocity $v_{b .0}=22 \mathrm{~m} / \mathrm{s}$ and they were spaced every $50 \mathrm{~cm}$. However, at the moment of damage, the wind load value was almost twice as high. Typically, membranes are laid loosely on an even surface, and then assembled with mechanical fasteners consisting of a screw and a plastic sleeve for roof structures [1]. Mechanical fastening should be based on the previously prepared analysis of suction and wind pressure loads, taking into account the characteristics of facilities and local conditions. By adopting the standardised guidelines, the designer determines the distance between assembled 
fasteners to ensure correct operation of a roof covering. In general, it is recommended to compact fasteners in the corner and perimeter zones of the roof since these areas are particularly exposed to wind action. Distances between fasteners in these zones, according to manufacturers' recommendations, should not exceed $0.5 \mathrm{~m}$, however, in corner zones, depending on the category of surface roughness as well as wind load zones, the spacing should be decreased and compacted to $0.25 \mathrm{~m}$. It is also important to precisely combine even the smallest components that jointly affect the tightness and durability of the entire roof covering and the work of the structure.

\section{ADDITIONAL INFORMATION}

The publication was financed within the framework of Ministry of Science and Higher Education programme as „Regional Initiative Excellence” in years 2019-2022, Project No. 005/RID/2018/19.

\section{REFERENCES}

1. European Technical Assessment ETA-07/0013 as of 17 March 2017. EJOT fasteners for flat roofs. Fasteners for mechanical fastening of roofing systems made of flexible waterproofing products (Europejska Ocena Techniczna ETA-07/0013 z dnia 17 marca 2017. EJOT łączniki do dachów płaskich. Łączniki do mechanicznego mocowania systemów pokryć dachowych $\mathrm{z}$ elastycznych wyrobów wodochronnych).

2. Ksit, B and Monczyński, B 2012. Damp insulation and hydroinsulation of flat roofs and terraces (Izolacje przeciwwilgociowe i przeciwwodne dachów płaskich i tarasów), Verlag Daschofer sp.z o.o.

3. Monczyński, B, Ksit, B and Szymczak-Graczyk, A 2019. Assessment of the effectiveness of secondary horizontal insulation against rising damp performed by chemical injection. IOP Conference Series: Materials Science and Engineering, 471, 052-063.

4. Nowogońska, B 2016. The Life Cycle of a Building as a Technical Object. Periodica Polytechnica Civil Engineering, 60(3), 331-336.

5. PN-77/B-02011:1977/Az1 Loads in static calculations. Wind load (Obciążenia w obliczeniach statycznych. Obciążenie wiatrem).

6. PN-EN 1991-1-4:2008/NA:2010 Eurocode 1. Loads on structures. Part 1-4. General loads. Wind loads (Eurokod 1. Oddziaływania na konstrukcje. Część 1-4. Oddziaływania ogólne. Oddziaływania wiatru.)

7. Report of the Institute of Meteorology and Water Management as of 19 January 2018 (Raport Instytutu Meteorologii i Gospodarki Wodnej z dnia 19.01.2018). 
8. Rawska-Skotniczy, A 2014. Loads on buildings and building structures according to Eurocodes (Obciażenia budynków i konstrukcji budowlanych wedtug Eurokodów), Wydawnictwo Naukowe PWN, Warsaw.

9. Regulation of the Minister of Infrastructure as of April 12, 2012 on technical conditions for buildings and their location-Journal of Law 2015.1422 as amended (Rozporządzenie Ministra infrastruktury z dnia 12 kwietnia 2012 roku w sprawie warunków technicznych, jakim powinny odpowiadać budynki i ich usytuowanie (Dz. U. 2015.1422 z późniejszymi zmianami).

10. Szymczak-Graczyk, A 2011. Wind load on buildings (Obciążenie wiatrem budynków). Acta Scientiarum Polonorum. Architectura, 10(4), 25-32.

11. Szymczak-Graczyk, A 2012. Snow load and safety of use of buildings (Obciążenie śniegiem a bezpieczeństwo użytkowania obiektów budowlanych). Aparatura badawcza i dydaktyczna, Tom XVII, Nr 4, 57-62.

12. Szymczak-Graczyk, A 2018. Icing effect on steel bar structures. Annual Set The Environment Protection, 20, 934-947.

13. ETAG 006 guidelines 2000. Fasteners for mechanical fastening of roofing systems made of flexible waterproofing products (Wytyczne ETAG 006 (2000). Systemy pokryć dachowych z elastycznych wyrobów wodochronnych mocowanych mechanicznie). ITB, Warsaw.

14. Żurański, JA and Gaczek, M 2008. Hurricane wind action on buildings (Oddziatywanie huraganowego wiatru na budowle). X Conference on Scientific and Technical Problems of Construction Expert Opinions, Warsaw - Miedzeszyn.

Editor received the manuscript: 04.08.2019 